\title{
THE CULTURAL BELIEFS OF THE VHAVENDA ON THE CAUSES AND TRANSMISSION OF SEXUALLY TRANSMITTED INFECTIONS
}

\author{
Fhumulani Mavis Mulaudzi \\ DLitt et Phil \\ Associate Professor, School of Nursing, North West University (Potchefstroom campus), Potchefstroom \\ Corresponding author: 20877749@nwu.ac.za
}

Keywords: grounded theory; women; sexually transmitted infections; Vhavenda; culture; beliefs

\begin{abstract}
Cultural and ethnic identity and folk beliefs play a decisive role in perceptions, attitudes and practices regarding health care and illness. Such beliefs and practices of a community may have an influence on the causes and transmission of diseases, including sexually transmitted diseases. The purpose of the study on which this article is based, was to describe cultural beliefs of the Vhavenda on the causes and transmission of sexually transmitted infections.

A qualitative research approach using grounded theory was used. In-depth interviews were held with thirteen keyinformants in the community and seven traditional healers. Snowball and theoretical sampling were used to identify the participants. The results showed that the concept "dirt" (uncleanliness) is viewed by the Vhavenda as the main cause of sexually transmitted infections (STIS). The understanding of "dirt" is placed in the context of uncleanliness in the form of vaginal discharges such as menstruation, post-abortion discharges and lochia (post-partum discharges). Women are viewed as carriers of STIs. Knowledge of cultural beliefs of the Vhavenda on the causes and transmission of STIs can serve as a point of departure in providing health education about sexually transmitted infections. The initiative may assist to facilitate change in clients' health behaviour and enabling health practitioners to render culturally congruent care.
\end{abstract}

\section{OPSOMMING}

Kulturele en etniese identiteit en volksgelowe speel 'n deurslaggewende rol in die persepsies, houdings en gebruike ten opsigte van gesondheidsorg en siekte. Sodanige oortuigings en die gebruike van 'n gemeenskap kan 'n invloed hê op die oorsake en oordrag van siektes, insluitend seksueel oordraagbare siektes. Die doel van die navorsing waarop hierdie artikel gebaseer is, was die beskrywing van kulturele oortuiginge van die Vhavenda ten opsigte van die oorsake en oordrag van seksueel oordraagbare infeksies.

'n Kwalitatiewe navorsingsbenadering met behulp van gegronde teorie is gevolg. Diepgaande onderhoude is met dertien sleutelinformante in die gemeenskap en sewe tradisionele genesers gevoer. Sneeubal- en teoretiese steekproewe is gebruik om die deelnemers te identifiseer. Die resultate toon dat die begrip "vuilheid" (onreinheid) by die Vhavenda gesien word as die hoofoorsaak van seksueel oordraagbare infeksies (SOI's). Die opvatting van "vuilheid" word gesien teen die agtergrond van onreinheid in die vorm van vaginale afskeidings soos menstruasie, afskeidings ná aborsie en lochia (postpartum-afskeidings). Vroue word gesien as draers van SOl's. Kennis van kulturele oortuiginge van die Vhavenda met betrekking tot die oorsake en oordrag van SOl's kan dien as vertrekpunt in die verskaffing van gesondheidsopvoeding ten opsigte van seksueel oordraagbare infeksies. Dié inisiatief kan help om verandering in kliënte se gesondheidsgedrag te fasiliteer en om dit vir gesondheidsorgpraktisyns moontlik te maak om sorg te lewer wat kultureel gepas sal wees. 


\section{INTRODUCTION}

Sexually transmitted Infections (STIS) are a major problem in South Africa. Statistics show that an estimated 250000 million cases of STIs are reported each year (UNAIDS, 2002:3). STIs are infections grouped together because they are spread by transfer of organisms from person to person during intimate sexual contact (Vlok, 2002:367). Sexually transmitted infections (STIS) can have serious repercussions for women's health, as well as the health of their children and sexual partners. STIS contribute to the incidence of pelvic inflammation, spontaneous abortions, ectopic pregnancies and cervical cancer. In addition, STIs are a major cause of infertility (Tanfer, Cubinns \& Billy, 1997:196).

STIs vary according to gender, culture, race, and socioeconomic status (Tanfer et al. 1997:196). Cultural related factors in the spread of STIs are emphasised by Reddy, Meyer-Weitz, Van den Borne and Kok (1999:392) who state that the social and cultural conditions of a society play an important role in sexual behaviour, which in turn has a strong bearing on the transmission and causes of sexually transmitted infections. The healthcare system of a society cannot be studied in isolation from other cultural aspects of that society. Helman (1996:152) asserts that patterns of sexual behaviour practised in certain cultures or societies may have an influence on the transmission of sexually transmitted infections. Socio-cultural practices, such as polygamy allow men to have more than one wife, thus placing women at risk of contracting STIS (Reddy et al. 1999:392). A study conducted by Ndubani and Hojer (2001:110) argue that in an area where traditional values permit men to have more than one wife, and where manhood seems to be often demonstrated through sex with a number of women, women will contract STIs as their men will be sleeping with other women. Traditional social norms perpetuate women's subordination to men and increase women's vulnerability to STIs (Go, Quan, Chung, Zenilman, Hanh \& Celentano, 2002:467).

Cultural practices such as widow inheritance may put women in danger of contracting STIs such as HIVIAIDS. For example, in a case where a husband inherits a widow (his brother's wife) without knowing that the brother died of HIVIAIDS complications. In that situation the husband and his wives will also contract the disease. Gausset (2001:518) argues that medical anthropologists demonised and criticised cultural practices such as polygamy, widow inheritance and circumcision without understanding the context in which the practices occur. He maintains that all rituals and practices had both benefits and disadvantages. It will therefore be advisable for health care workers to learn more about the beliefs and practices related to health care.

A study conducted by Moss, Bentley, Maman, Ayuko, Egessah, Sweat, Nyarang'o, Zenilman, Chemtai and Halsey (1999:95) on foundations for effective strategies to control sexually transmitted infections, revealed that in Kenya sexually transmitted infections are termed "women's diseases". A similar study conducted in Morocco, also pointed out that women are viewed as people who spread STIs thus, so that STIs are viewed as women's illnesses (Manhart, Dialmy, Ryan \& Mahjour, 2000:1369).

The WHO (2003:1) states, "women are probably more susceptible than men to infection from HIV in any given heterosexual encounter, due to biological factors such as the greater area of mucous membrane exposed during sex in women than in men; the greater quantity of fluids transferred from men to women; the higher viral content of male sexual fluids; and the micro-tears that can occur in vaginal (or rectal) tissue from sexual penetration". Tanfer et al. (1997:196) concur with the above assertion when they indicate that women are prone to STIs due to their biological disposition, sexual behaviour that increases the risk of infection and differences in preventive health behaviour and lack of access to healthcare services. The biological make-up of women makes it difficult for them to detect STIs in the early stages. As a result, some women remain unaware of the fact that they have contracted an STI until complications occur. Women have normal vaginal discharges and may therefore fail to recognise that the amount and colour of the discharge has changed. This lack of recognition may be detrimental as it may cause ascending infections, which may lead to pelvic inflammatory diseases, which in turn may give rise to infertility.

Presently, STIs are included in the nursing curriculum but community beliefs and sexual behaviour practices that may influence the causes and transmission of STIS are not included. Leininger (1999:64-65) points out that professional health workers usually view indigenous 
practices as inadequate, primitive, antiquated, superstitious, magical and quackery. This view denies nurses the opportunity to understand the values, norms, beliefs, needs and practices of the belief systems and health practices of the people they serve. It is therefore vital that nurses obtain more knowledge on beliefs and behaviour that may influence the care they render.

It is also essential for nurses to learn more about the cultures in which they practice in order to provide culture-specific healthcare practices. In this article, the focus is on the Vhavenda. It is necessary to point out that the Vhavenda practice polygamy, and multipartnered sexuality is common and widely accepted for Vhavenda men. In contrast, Vhavenda women are expected to be obedient and to live in absolute fidelity to one man (Phaswana, 2000:204). This prompted the researcher to explore the cultural beliefs of the Vhavenda on the causes and transmission of sexually transmitted infections. The beliefs and practices surrounding causes and the spread of STIs among societies need to be addressed for treatment to be effective.

\section{RESEARCH PURPOSE}

To explore and describe cultural beliefs of the Vhavenda on the causes and transmission of sexually transmitted infections.

\section{RESEARCH APPROACH AND METHODS}

A qualitative research approach was used. De Vos, Strydom, Fouché and Delport (2002:269) assert that the goal of qualitative inquiry is to understand the meaning of a phenomenon from the perspective of the people experiencing it. Within the qualitative approach, grounded theory was the main methodological point of departure for the study. Grounded theory allows the researcher to explore and get more information without delineating boundaries of the research activity (Strauss \& Corbin, 1990:11). The cultural beliefs of the Vhavenda on the causes and transmission of STIs have never been studied. Grounded research was therefore chosen because there is very little research done on the topic (Streubert \& Carpenter, 1999:149).

\section{Population and sampling}

The study was conducted in the rural areas of the
Limpopo Province, in the Vhembe district. The majority of people that reside in Vhembe district belong to the Vhavenda ethnic group. Unlike the sampling done in quantitative studies, in grounded theory sampling cannot be planned before embarking on the study. The specific sampling decisions evolve during the research process itself (Wheeler \& Holloway, 2002:157). Older women aged between 40 to 65 years formed the majority of participants because of their experience in child bearing, wifehood and as the educators of young children. Among the Vhavenda, older women are respected in society due to their personal experience. Their expertise is usually recognised during rituals such as initiation schools. Their position in society puts these women in a good position to be transmitters of knowledge in an indigenous knowledge context concerning pregnancy, sexually transmitted infections, childbirth and infancy. The key-informants identified each other and the process facilitated a snowball effect (network sampling) (Burns \& Grove, 1997:307). Twenty participants were interviewed, thirteen of whom were key-informants. The other seven participants were traditional healers who were known by the other informants to be specialists in the treatment of STIs. The traditional healers were included based on theoretical sampling. As data collection continued it was felt that traditional healers should also be interviewed to shed more light on other aspects pertaining to transmission and causes of STIs on which they may provide expert knowledge (Strauss \& Corbin, 1990:180).

\section{DATA COLLECTION}

In-depth interviews were conducted in the privacy of the participants' own homes. Participants signed consent forms before answering the questions. The question asked was: What are the cultural beliefs of the Vhavenda on the causes and transmission of sexually transmitted infections?

The interviews were conducted by three research assistants from the University of Venda. They were selected on the basis that they were from the Vhavenda ethnic group, so they knew the language and culture of the participants. The assistants were postgraduate students from three different departments, namely Nursing Science, Gender Studies and Psychology. They were trained in interviewing and probing skills before the interviews took place. The interviews were recorded 
using a tape recorder and notes were taken.

\section{DATA ANALYSIS}

Data collection and data analysis occurred simultaneously. Interviews were conducted in Tshivenda and later translated into English by a language practitioner for general clarity. The researcher compared the recording and the transcribed copy to update and correct any omissions that might have occurred during transcription. In grounded theory data analysis and data collection occur simultaneously. Data are analysed through open coding, axial coding and selective coding. Open coding is the descriptive mode where the researcher identifies, names, categorises and describes the phenomenon. In axial coding the categories developed during open coding are related to properties to seek more understanding and meaning of the phenomenon. The last step is selective coding where one category is chosen to be a core category which will be related to all categories to formulate a theory. The researcher used open coding which is the first step in coding. The researcher went through each interview, and made notes and sorted the data into categories. During this process the researcher sees the world through the eyes of the participants. This article will only report on cultural beliefs of the Vhavenda on the causes and transmission of sexually transmitted infections which is the result of the open coding (Strauss \& Corbin, 22-72).

\section{MEASURES TO ENSURE TRUSTWOR- THINESS}

The research adopted various strategies to ensure trustworthiness of data as suggested by Lincoln and Guba (1985:290-331) and Krefting (1991:214-222). See Table 1.

\section{ETHICAL CONSIDERATIONS}

The researcher obtained permission from the University of South Africa to conduct the research. The researcher also applied to healthcare authorities at the ethics committee of Limpopo Province for permission to conduct the research in the province. The researcher was invited to present her proposal orally. Thereafter, a letter of permission was granted. The permission to speak with the elders was requested from the chief. The researcher and the research assistants negotiated the setting. Being from the same cultural group, they were familiar with the protocols, for example dressing down and special ways of greeting the elders such as genuflecting as expected in the salutary protocols of the Vhavenda. To gain co-operation of the participants, a consent form was read and interpreted to each one of them in Tshivenda, the language that they understood. The nature and extent of the research was explained to each participant before the interview. Participants were also informed that some of the questions may be sensitive. Participants were also informed that if they feel uncomfortable to answer some of the questions asked they may stop the interview or refuse to answer some of the questions asked without any fear of victimisation. Illiterate participants were asked to put a cross where they were supposed to put a signature, to signify their acceptance to participate in the study (De Vos et al. 1998:331). Literate participants were requested to read and sign a consent form. The interviewees' rights as regards to the confidentiality of findings were guaranteed (Burns \& Grove, 1997:89). The interviews were held at the participants' own homes to ensure privacy. The audio-taped interviews were kept under lock and key and were destroyed after the verbatim transcriptions of the interviews. The researcher and research assistants tried their utmost to establish a good relationship so as to ensure trustworthiness and to enable the interviewees to be free and open during the research process. Good rapport has to be established prior to the introduction of the topic and its aim to gain trust from the participants. The research assistants were taught to be humble and to show respect to the elders to create a relaxing atmosphere.

\section{DISCUSSION OF FINDINGS}

The findings of the study on which this article is reporting, showed that among the Vhavenda, women are regarded as carriers of STIs. These findings correspond with studies conducted in Morocco and Kenya, where it was also found that STIs are viewed as a women's illness (Ndubani \& Hojer, 2001:110; Manhart et al. 2000:1369). The beliefs and views on causes of diseases may differ. The Vhavenda have their own understanding of the pathophysiology of STIs, which will be shown and explained in Figure 1.

Figure 1 shows that the Vhavenda regard STIs as infections caused by having sexual intercourse with a 
Table 1: Strategies used to ensure trustworthiness of data

\begin{tabular}{|c|c|c|}
\hline STRATEGY & CRITERIA & APPLICATION \\
\hline Credibility & Member checking & $\begin{array}{l}\text { - Follow-up interviews were conducted to validate the data. } \\
\text { - Feedback was provided to the participants to ensure that } \\
\text { information they provided has been captured properly. }\end{array}$ \\
\hline & Prolonged engagement & $\begin{array}{l}\text { - Ample time was spent with the participants. } \\
\text { - The use of the participants' own language enhanced } \\
\text { communication, and consequently the participants } \\
\text { volunteered more sensitive information because of the } \\
\text { increased rapport between the interviewers and the } \\
\text { participants. }\end{array}$ \\
\hline & Field notes & $\begin{array}{l}\text { - Non-verbal cues were observed and recorded in the field } \\
\text { notes. }\end{array}$ \\
\hline & Peer review & $\begin{array}{l}\text { - Meetings were held with research assistants and } \\
\text { supervisors to discuss the findings. } \\
\text { - The research process was discussed with experts. }\end{array}$ \\
\hline Transferability & & $\begin{array}{l}\text { - "Thick descriptions" on the causes and transmission of } \\
\text { STI'S according to the Vhavenda's beliefs were provided. }\end{array}$ \\
\hline Dependability & $\begin{array}{l}\text { Dense description of } \\
\text { methodology }\end{array}$ & $\begin{array}{l}\text { - The method used was described thoroughly. } \\
\text { - Research assistants had to compare their notes, but also } \\
\text { had to code and recode their data until agreement was } \\
\text { reached. }\end{array}$ \\
\hline Confirmability & Triangulation & $\begin{array}{l}\text { - The supervisors of the study also listened to the tapes to } \\
\text { verify the conclusions, interpretations and } \\
\text { recommendations. } \\
\text { - Field notes and memos were checked and compared. } \\
\text { The researcher went back and forth to compare and verify } \\
\text { the data. } \\
\text { - Investigator triangulation was achieved as research } \\
\text { assistants from different fields of study were used. }\end{array}$ \\
\hline
\end{tabular}

woman who is having a discharge. The participants indicated the discharges they were referring to as "menstrual discharges", "post-abortion discharge" and "postdelivery discharge". The characteristics of vaginal discharge are also regarded by the participants as a symptom of decay or moulding setting in.

This view is supported by Tanfer et al. (1997:201) when they state, "With its moist nature, the vagina is often thought of as providing an ideal breeding place where bacteria may thrive, thus causing infection. It cannot be disputed that biologically and physiologically the vagina is indeed vulnerable to infection". These authors further assert that "among women developmental changes such as the type of lining in the genital tract, the resident flora and acidity of the vagina and the characteristics of the cervical mucus affects susceptibility of STIs and their causes".

The discharges that are regarded as infectious are bleeding from the raw uterus after abortion, post-delivery lochia, and the endometrial tissues shed during men- 


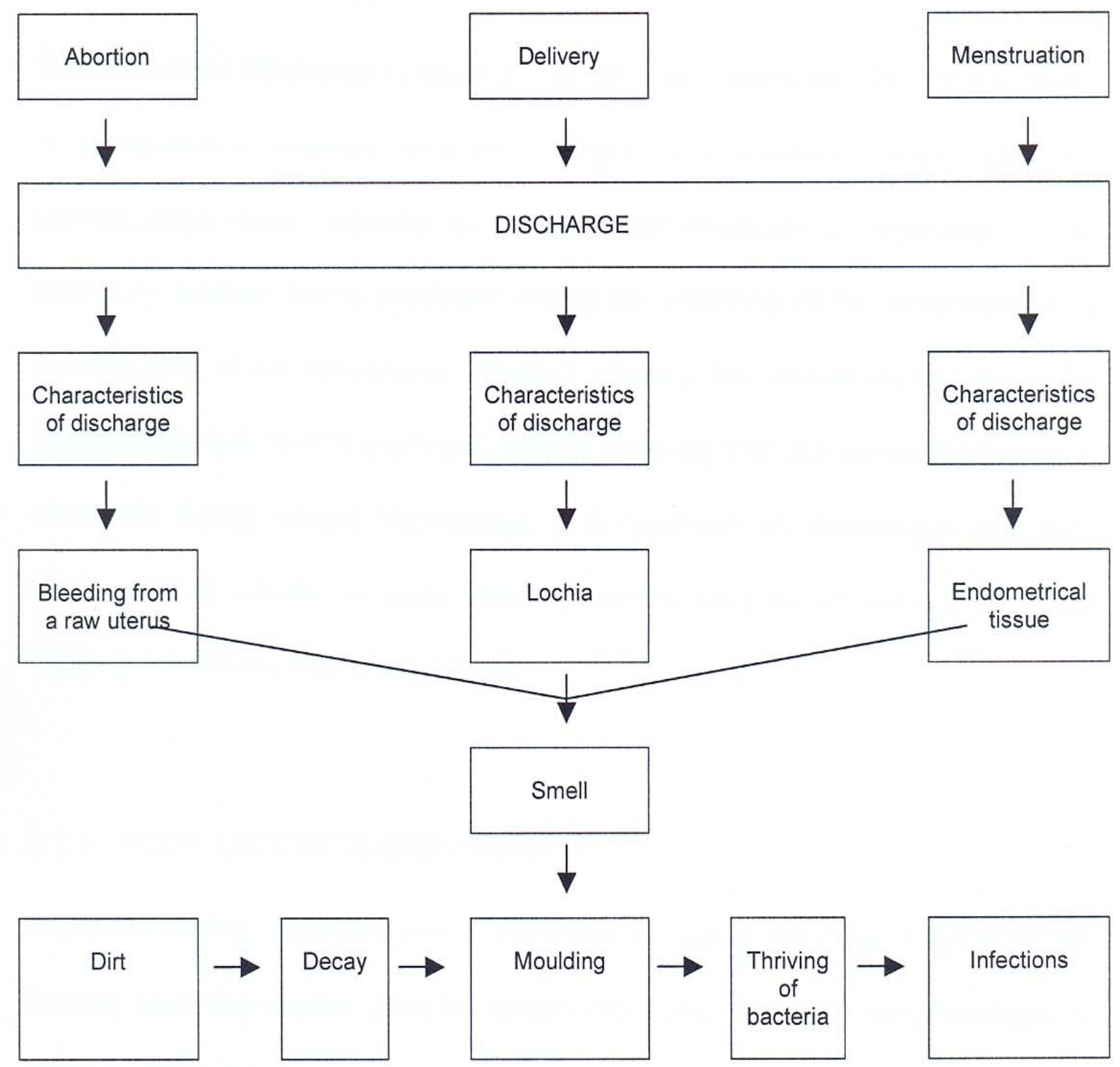

Figure 1: The understanding of the Vhavenda on the pathophysiology of sexually transmitted infections

struation. In the case of post-abortion discharges, the participants indicated that such discharges are usually offensive and the woman should have a normal menstruation cycle before she is allowed to resume sexual intercourse. It is believed that during normal menstruation the uterus is cleansing itself and all remaining tissues of conception will be removed. The lochia after delivery has an offensive smell, which indicates that the discharges are also not yet normal. The participants explained that blood is viewed as dirty. The dirt causes decay and moulding, which allow bacteria to thrive, thus causing infection.

\section{Dirt (women's physiological discharges)}

with discharges was identified by the participants as the main cause surrounding sexually transmitted infections. Women are also referred to as "dirty" when they are associated with such taboos as they have not yet undergone the ritual of a cleansing ceremony after the death of a husband. It is a cultural practice that if a man dies, the wife must be cleansed with herbal remedies. This practice is said to rid women of diseases and infections which could be dangerous to a man who will have sexual intercourse with a woman who has not been cleansed. So-called "dirt" is further defined in the form of vaginal discharges such as menstruation, postabortion discharge and post-delivery discharge, which will be described in detail. 


\section{Menstruation}

A woman who is menstruating is said to be "dirty" in traditional Vhavenda terms. She is therefore not expected to have sexual contact with a man. It is believed that menstrual discharges make a man physically weak. Furthermore, the dirty blood is believed to cause infertility to the male partner by blocking the route of seminal fluids. This view has been asserted by participants with one of them saying, "Then amongst men there is this thing of having sexual relations with a menstruating woman. What happens is that your nerves become thinner and they become painful. That is why if such a person bends at the waist for a long period, to unbend becomes a problem. If he forces to unbend there is a noise like that of a joint getting back in its rightful place. That's why in Tshivenda we use 'Tshipeiti' (enema) to treat this".

In modern medicine, menstruation is regarded as the shedding of dead endometrial tissue. Tanfer et al. (1997:201) maintain that physiological changes related to the menstrual cycle, pregnancy and contraceptive use might change the normal flora, thus influencing women's increased risk to contract STIs. These authors further state that the menstrual cycle appears to influence the risk of upper reproductive tract infection in women.

\section{Post-delivery discharges}

Participants indicated that postpartum discharges are strongly believed to be infectious. It is widely believed that when a man engages in sexual intercourse with a woman who has just delivered, he may suffer from weakness and other physical health-related symptoms. To avoid these consequences during post-delivery, a woman has to move from the main hut and has to sleep with her mother-in-law who should also take care of her. The following quotation is applicable: "Precautions are taken to avoid spread of STIs a woman is separated form the husband and asked to sleep with the mother-in-law. Nowadays man contract diseases because they sleep with their wives prematurely".

In a similar study conducted in Ghana by Mill and Anarfi (2002:325), it was revealed that women are encouraged to practice post-delivery sexual abstinence. They further maintain that the practice of a woman being sepa- rated from the husband is intended to protect men from sexually transmitted infections believed to be caused by lochia (post-delivery discharges). In the case where men are separated from their wives for a year or more, men tend to have extramarital affairs thus subjecting women to the risk of contracting STIs.

The critics of monogamy cite the above examples to illustrate that monogamy is an unrealistic method of preventing transmission of sexually transmitted infections. In polygamy, it is easy for healthcare providers to trace contacts easily in cases of infections, as the husband's wives are all known (Gausset, 2001:517). In support of polygamy, one of the participants pointed out: "Why would a man go outside the marital home for sex when he had his own harem at home? As for the wives, they were all bound to their husband. These days some of these diseases are a result of men having sexual relations with their wives immediately after the wife has given birth and the womb is still dirty or unclean".

The participants went further and explained that having more than one wife allows women to have enough rest after delivery. They also maintain that this is a good way of spacing children compared to the family-planning methods used in modern medicine, which they perceive as weakening women's health. A woman is also not allowed to cook until she no longer has postdelivery discharges; neither is she allowed to have sexual contact while she is still breastfeeding. There is a strong belief that breast milk can be diluted by the seminal fluid. Such breast milk will not have enough nutrients and as a result the baby will suffer from a disease called "lukala". The description of "lukala" is that it is more or less similar to marasmus (malnourishment) in modern medicine. During this period, the man is at liberty to sleep with his other women where polygamy is practised.

\section{Post-abortion discharges}

Post-abortion discharges were described as not only very dangerous but even fatal. A woman who has had an abortion is not allowed to have sexual relations until she has had her normal menstruation. It is believed that normal menstruation will cleanse her from the socalled "dirt" that she is harbouring due to the abortion. A man who has sexual contact with a woman who has 
had an abortion will contract a disease called "divhu". The literary meaning of the word 'divhu' means falling into the trap and it is assumed that the disease deplete the immunity system. One of the participants said: "A man who has slept with a woman who had abortion contracts "divhu". This is when a man has sexual relations with a woman who has aborted and her womb is not yet clean. His penis swells and his fingernails, eyes and teeth turn white. Lips become chapped. The patient loses considerable weight and the bladder stops working. The patient's skin becomes dry and the voice changes to a shrill tone. Some sufferers die as a result of the non-functioning of the bladder".

The above findings are supported in the literature by Louistanau and Sobo (1997:38) when they indicate, "In such societies, which are patriarchal, men are in control, and the more patriarchal a society is the less important women and all that is associated with them are deemed inferior. This devaluation serves as an ideological function, supporting male domination. For example, menstruation and birth become associated with nastiness and uncleanliness; menstruating women are banned from certain places or tasks". One of the participants said: "Menstruation makes a woman dirty. It is prohibited to have sex with a woman during those period as you can contract STIs".

Contrary to the above view, men's seminal and prostatic fluids may contain elements with marked antibacterial activity (Tanfer et al. 1997:201). It is quite interesting to note that, although women's discharges are physiological normal, communities may have their own perceptions, which are influenced by patriarchy, beliefs and practices of that particular society.

\section{CONCLUSIONS AND RECOMMEN- DATIONS}

Among the Vhavenda, the concept "dirt" or uncleanliness is equated with contamination or a contagious condition that is widely regarded as the cause of all sexually transmitted infections. The concept of dirt is placed in the context of uncleanliness in the form of discharges, such as menstruation and lochia (postpartum discharges). Unfortunately, women are considered the main carriers of so-called "dirt" (by men and women) and are regarded as being responsible for the spread of STIs. Factors such as women's biological make-up as well as socio-cultural beliefs and practices that affect sexual behaviour put women at a higher risk of acquiring STIs than men. Yet men are also responsible for transmission of STIs due to socio-cultural factors that allow them to practice infidelity.

The findings of the study on which this article is based, show that women are discriminated against due to the biological factors beyond their control. Biological discharges are normal and part of the normal cycle of a woman.

Knowledge of the cultural beliefs of the Vhavenda on the causes and transmission of STIs can serve as a point of departure in providing health education about sexually transmitted infections. The findings emphasise the importance of avoiding sexual intercourse during periods that the Vhavenda view as unclean and unhygienic. Health education must be given to the community on physiological discharges such as menstruation, post-abortion discharges and post-partum discharges in cultural acceptable terms. Cleanliness and the aseptic technique are part of the curriculum of health practitioners, however the understanding of cleanliness is viewed differently in the case of the Vhavenda. Health care practitioners must use this opportunity to compile modules which will incorporate and integrate cultural beliefs that are harmless to health education. Information and advice must be given on how to deal with cultural practices that are harmful to health. For example, in terms of widow inheritance the community may be advised that a couple who want to practice widow inheritance must go for HIVIAIDS testing and counselling. The use of case studies, role plays and community profiles may also be used during health education to address causes and transmission of STIs.

This results of the study on which this article is based, show that there is a need to start health-promotion initiatives in the communities to promote awareness of the dangers of cultural practices that are detrimental to women's health. The initiative must not be based on criticising cultural practices but to make beliefs and practices safer in a way that is culturally acceptable to people. For example, a man who has more than one wife maybe encouraged to use condoms to avoid the spread of STI's rather than to be told that polygamy is unacceptable. 
Training guidelines for health workers should be designed to enable health workers to understand the beliefs and practices that affect the health-illness continuum. The initiative may assist nurses in rendering culturally congruent care such as preventive and promotion strategies of sexually transmitted diseases and promotion of rest during the post-partum period. These guidelines may serve as a basis for further research among other cultural groups in Limpopo Province and South Africa at large. The guidelines must encourage respect and ways of incorporating harmless cultural practices in primary health care. Methods of cultural sensitivity when dealing with handling cultural harmful practices must also be outlined.

\section{REFERENCES}

BURNS, N \& GROVE, KS 1997: The practice of nursing research: Conduct, critique \& utilization; $3^{\text {rd }}$ edition. Philadelphia: WB Saunders

DE VOS, AS; STRYDOM, H; FOUCHÉ, CB \& DELPORT, CSL 2002: Research at grass roots level. Pretoria: Van Schaik.

GAUSSET, Q 2001: AIDS and cultural practices in Africa: The case of Tonga (Zambia). Journal of Social Science and Medicine, 52(4):509-518.

GO, VF; QUAN,VM; CHUNG, A; ZENILMAN,JM; HANH, VT \& CELENTANO, DC 2002: Gender gaps, gender traps: Sexual identity and vulnerability to sexually transmitted diseases. Social Science and Medicine, 55(3):467-481.

HELMAN, CG 1996: Culture, health and illness; $3^{\text {rd }}$ edition. Boston: Wright.

KREFTING, L 1991: Rigor in qualitative research: The assessment of trustworthiness. American Journal of Occupational therapy, 45(3):215-217.

LEININGER, M 1999: Transcultural nursing concepts, theories and practices. New York: John Wiley.

LINCOLN, YS \& GUBA, EG 1985: Naturalistic inquiry. Beverly Hills: Sage.

LOUSTAUNAU, MO \& SOBO EJ 1997: The cultural context of health, illness and medicine. London: Bergin \& Garvey.

MILL, JE \& ANARFI, JK. 2002: HIV risk environment for Ghanaian women: Challenges to prevention. Social Sciences and Medicine, 54(3):325-337.

MOSS, W; BENTLEY, M; MAMAN, S; AYUKO, D; EGESSAH, O; SWEAT, M; NYARANG'O, P; ZENILMAN, J; CHEMTAI, A\& HALSEY, $N$ 1999: Foundations for effective strategies to control sexually transmitted infections: Voices from rural Kenya. AIDS Care, 11(1):95-113.

MANHART, LE; DIALMY, A; RYAN, CA \& MAHJOUR, J 2000: Sexu- ally transmitted diseases in Morocco: Gender influences on prevention and healthcare seeking behaviour. Social Science and Medicine, 50(10):1369-1383.

NDUBANI, P \& HOJER, B 2001: Sexual behaviour and sexually transmitted diseases. Health Policy and Planning, 16(1):107112.

PHASWANA, NS 2000: Marital problems in religiously mixed marriages amongst the Vhavenda people of South Africa: An AfricanChristian perspective. Pretoria: University of South Africa (Unpublished PhD dissertation).

REDDY, P; MEYER-WEITZ, A; VAN DEN BORNE, B \& KOK, G 1999: STD-related knowledge, beliefs and attitudes of Xhosa-speaking patients attending STD primary health-care clinics in South Africa. International Journal of STD \& AIDS, 10(6):392-400.

STREUBERT, HJ \& CARPENTER, DR 1999: Qualitative research in nursing; $2^{\text {nd }}$ edition. Philadelphia: Lippincott.

STRAUSS, A \& CORBIN, J 1990: Basics of qualitative research: Grounded theory procedures and techniques. Newbury Park, California: Sage.

TANFER, K; CUBBINS, LA \& BILLY, OJ 1997: Gender, race, class and self-reported sexually transmitted disease incidence. Family Planning Perspective, 27(5):196-202.

UNAIDS 2002: AIDS Epidemic update-December 2002. Geneva: UNAIDS.

VLOK, ME 2002: Manual of community nursing and communicable diseases. Landsdowne: Juta.

WHEELER, S \& HOLLOWAY, I 2002: Qualitative research in nursing. Oxford: Blackwell.

WORLD HEALTH ORGANIZATION (WHO) 2003: Integrating gender into HIVIAIDS Programmes. Geneva: WHO. 